\title{
Review on initial alignment efficiency and subject experience during fixed mechanotherapy with Self ligating brackets
}

\author{
K.Mohamed Afradh ${ }^{1}$, Ravindra kumar Jain ${ }^{2}$ \\ ${ }^{1}$ (Intern, Saveetha Dental College) \\ ${ }^{2}$ (Senior Lecturer, Department of Orthodontics, Saveetha Dental College)
}

\begin{abstract}
Introduction: This review is aimed at studying the initial alignment efficiency and pain experience of Self ligating brackets and comparing them with conventionally ligated brackets. Materials and Methodology: Electronic databases were searched without limits for this review (Pubmed, Google, Medline). Studies that addressed initial alignment and pain experience of self ligating brackets were analysed and reviewed. In addition, a manual search was done to search the missed articles during electronic search. Results: 5 studies were included out of which three were randomised control trials and two were clinical control trials. Three review articles on Self ligating brackets were obtained. Subjective pain experience and initial alignment of Self ligating brackets were analysed. Conclusion: Self ligating brackets are not superior compared to conventionally ligating brackets in initial alignment and levelling stage. Pain experience was independent with both the bracket types initially, but on insertion and removal of arch wire, more pain was experienced with self ligating brackets.
\end{abstract}

Keywords: Initial Alignment Efficiency, Pain Experience, Self Ligating Brackets.

\section{Introduction:}

Stolzenberg[1] , first described self ligating brackets more than 70 years ago followed later by many additions . Proposed limitations of conventional ligating brackets include higher frictional values, failure to maintain full arch wire engagement, force decay of elastics, impeded oral hygiene and time consuming clinical procedures [2].

Self ligating brackets overcome these drawbacks by providing more certain full arch wire engagement, reduced friction between bracket and arch wire, faster arch wire removal and ligation and lesser chair side time [2]. Reduced friction between arch wire and self ligating bracket have been quoted by numerous authors compared with conventional brackets [2,3]. Anchorage conservation with self ligating brackets is mainly due to lower forces per unit area applied [4].

This review is aimed at collecting and analysing the literature on initial alignment efficiency and pain experience of self ligating brackets and comparison of initial alignment efficiency of self ligating brackets with conventionally ligated brackets.

\section{Materials And Methods:}

The electronic databases searched for this review were PubMed, google and Scopus from 1999 to 2012.

\subsection{Inclusion Criteria:}

The key words used for search were "Self ligating brackets" OR "Self ligation". Approximately 35 articles were found out of which 5 met the inclusion criteria.

The Inclusion Criteria is as follows.

- Articles on initial alignment efficiency of self ligating brackets and articles on comparative alignment efficiency between self ligating and conventional ligating brackets.

- Articles on subject experience with self ligating brackets.

Three of them were Case Control Trials and two were Randomised Control Trials. Three systematic reviews on self ligating brackets were referred for writing this review article. (ref to Table no 1)

\section{Results:}

The electronic search on the database identified 35 articles out of which 15 were full articles. Out of those 15 articles, only 5 met the inclusion criteria in which 2 were Randomised Clinical Trials and 3 were Case Control Trials. 3 systematic review articles were referred. All these review articles were published in English. The mean age of these patients were found to be around 16 to 21 yrs. Among the five articles, 4 articles investigated the efficiency of initial alignment of self ligating brackets and two studied subject experience also. 


\subsection{Alignment Efficiency:}

Abdul Wahab et al[6] stated that teeth alignment with Conventionally ligating brackets was faster during the second and third month compared to Self ligating brackets, but there was no statistical difference during the third and fourth month between Self ligating and Conventionally ligating brackets. The average percentage crowding alleviation was higher in Conventionally Ligating brackets (98\%) compared to Self Ligating brackets $(67 \%)$.

A study by Miles et al [5] demonstrated that during the initial alignment stage, $0.2 \mathrm{~mm}$ greater irregularity was observed with self ligating brackets than the conventionally ligated brackets. Scott et al [8] demonstrated no significant difference in the rate of initial alignment between Self Ligating brackets and Conventionally Ligating brackets.

Miles et al [9] in his study found that there was no difference in alignment efficiency between Self Ligating Brackets and Conventionally Ligating Brackets at the end of 20 weeks.

\subsection{Subject Experience:}

Fleming et al [7] studied pain experience at different time periods ( $4 \mathrm{hrs}, 24 \mathrm{hrs}, 72 \mathrm{hrs}$ and 7 days) following appliance placement and stated that pain experience was independent of bracket type in the first 24 hours.

Miles et al [5], reported more discomfort in the first few days after placement of initial 0.014 arch wire with Damon 2 Self ligating brackets. However when engaging 0.016x0.025 inch wire more patients reported discomfort with Damon 2 than with Conventionally ligated brackets.

\section{Discussion:}

Five studies included in the review investigated the alignment efficiency and subject experience with Self ligating brackets. All Self ligating brackets were passive type (Damon, Onco, Smartclip, 3M unitec). Passive self ligating brackets are known for very low friction values, however an assumption has been made that with low friction comes more rapid alignment and reduction in treatment time. The study by Miles 2006[5] has clearly demonstrated that Self ligating brackets did not perform any better than conventional twin bracket, and Self ligating brackets had $0.2 \mathrm{~mm}$ irregularity at the end of alignment and levelling. This could be attributed to lack of engagement of 0.014 inch niti wire in the Self ligating brackets, allowing $8.5^{\circ}$ of rotational play compared with the theoretically fully engaged conventional twin bracket, the second $0.016 \times 0.025$ arch wire was more active in the passive slot of Self ligating brackets but was not fully engaged. Abdul Wahab et al [6] in his study concluded that over a period of 4 month aligning and levelling phase, the comparison of difference in the overall tooth alignment for Little's Irregularity Index Score showed faster changes for conventionally ligating brackets when compared with self ligating brackets. This can be explained by the fact that full arch wire engagement with maximum contact of the arch wire with the bracket slot was easily achieved with twin bracket. On rotated tooth surfaces, the metal slot of the Self ligating brackets could not be closed due to excessive bending of arch wire at the end of first month, this resulted in no engagement of the arch wire within the Self ligating brackets, hence it affected the rate of tooth movement in terms of relieving crowded cases. In an in vivo study by Miles et al 2005 [9], comparison of alignment efficiency of Self ligating brackets with conventionally ligating brackets was studied in the mandibular arch. The author found at the end of 20 weeks period, the Self ligating brackets were no more effective in reducing irregularity than the conventionally ligated twin brackets. Arch dimensional changes with Conventionally ligated and Self ligated brackets appeared to be similar. Identical levels of incisor proclination and intercanine expansion [11] was noted on both the systems. Another study have suggested that greater mandibular intermolar expansion developed during alignment with Self ligating brackets $[12,13]$.

Appliance related pain is believed to be very high at 24 hours to 3 days. But on adjustment of the appliance, pain is found to subside near baseline in about 5 to 7 days postoperatively ${ }^{[10]}$. Overall pain experience at each time interval was independent of bracket type. Due to the inability to control pain using analgesics, it leads to further usage of pre-emptive analgesics, particularly in patients with low pain threshold. Fleming et al[7] concluded that pain experience was independent of the bracket type but subjects who received Self Ligating brackets recorded more pain during both wire removal and insertion than Conventionally Ligating brackets. Pain experience was found to be same for all bracket type at each time interval. However studies have quoted that there is more pain experience with Conventionally ligating brackets when compared to self ligating brackets [5]. During rectangular arch wire insertion and removal, greater pain was experienced with Self Ligating brackets. 


\section{Tables And Figures:}

\section{TABLE-1: Summary of Included Research}

\begin{tabular}{|c|c|c|c|c|}
\hline Study & Methods & Participants & Interventions & Outcomes \\
\hline PG Miles et al 2006[5] & $\begin{array}{l}\text { A split mouth design } \\
\text { was analysed at } 10 \\
\text { weeks and } 20 \text { weeks. } \\
\text { CCT }\end{array}$ & $\begin{array}{l}\text { Numbers of } \\
\text { participants were } \\
58 \text { divided in to } \\
\text { two groups. Mean } \\
\text { age of } \\
16.3 \text { yrs(males- } \\
18 \text {,female-40). }\end{array}$ & $\begin{array}{l}\text { Victory MBT and } \\
\text { Damon } 2 \text { brackets were } \\
\text { placed in alternative } \\
\text { quadrants of lower arch. }\end{array}$ & $\begin{array}{l}\text { Rate of initial } \\
\text { alignment in the } \\
\text { lower is 3-3.Pain } \\
\text { experience at chair } \\
\text { side was observed. } \\
\text { Bracket failure } \\
\text { rates were also } \\
\text { recorded. }\end{array}$ \\
\hline $\begin{array}{l}\text { Rohaya Megat Abdul } \\
\text { Wahab et al 2011[6] }\end{array}$ & $\begin{array}{lrr}\text { CCT. } & \text { Observed at } \\
\text { every } 4 & \text { months } \\
\text { interval. } & & \\
& \end{array}$ & $\begin{array}{l}29 \text { patients. Mean } \\
\text { age } 20.3 \text { yrs. } 10 \\
\text { males and } 19 \\
\text { females }\end{array}$ & $\begin{array}{l}14 \text { patients were } \\
\text { observed with SLB and } \\
15 \text { patients were } \\
\text { observed with CLB }\end{array}$ & $\begin{array}{l}\text { Little's irregularity } \\
\text { index was used to } \\
\text { assess the overall } \\
\text { changes } \\
\text { alignment in } \\
\text { levelling. }\end{array}$ \\
\hline $\begin{array}{l}\text { P.S. Fleming et al } \\
\text { 2007[7] }\end{array}$ & 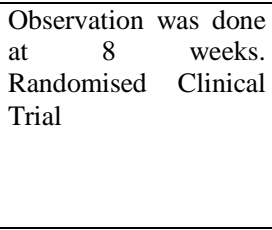 & $\begin{array}{l}22 \text { males and } 43 \\
\text { females a total of } \\
65 \text { patients } \\
\text { participated. Mean } \\
\text { age of the } \\
\text { participants is } \\
16.28 \mathrm{yrs}\end{array}$ & $\begin{array}{l}2 \text { Groups were taken. } \\
\text { Group } 1-\text { Smartclip for } \\
32 \text { patients. } \\
\text { Group 2- Victory for } 33 \\
\text { patients. }\end{array}$ & $\begin{array}{l}\text { Rate of initial } \\
\text { alignment in the } \\
\text { lower arch 6-6. }\end{array}$ \\
\hline Paul Scott et al 2008[8] & $\begin{array}{l}\text { Multicenter } \\
\text { Randomised clinical } \\
\text { trial. }\end{array}$ & $\begin{array}{lr}62 \text { patients } & (30 \\
\text { female and } & 32 \\
\text { male }) . \text { Mean age } \\
\text { of } 16.27 \mathrm{yrs} \text {. }\end{array}$ & $\begin{array}{l}2 \text { groups were analysed. } \\
\text { Group 1- Damon } 3 \\
\text { brackets in } 33 \text { patients. } \\
\text { Group 2- Synthesis } \\
\text { conventional ligation } \\
\text { brackets- } 29 \text { patients. }\end{array}$ & $\begin{array}{l}\text { Rate of initial } \\
\text { alignment in lower } \\
3-3 \text {. }\end{array}$ \\
\hline PG Miles et al 2005[9] & $\begin{array}{lr}\text { CCT. } 8 \text { weeks of } \\
\text { observation } & \text { after } \\
\text { mandibular } & \text { arch } \\
\text { alignment. } & \end{array}$ & $\begin{array}{l}32 \text { females and } 26 \\
\text { males, a total of } \\
48 \text { patients. Mean } \\
\text { age of } 17.1 \text { years. }\end{array}$ & $\begin{array}{l}\text { Group 1: Smart clip for } \\
24 \text { patients. } \\
\text { Group } 2 \text { : } \quad \text { Victory } \\
\text { brackets for } 24 \text { patients. }\end{array}$ & $\begin{array}{l}\text { Rate of initial arch } \\
\text { alignment observed } \\
\text { for lower arch 3-3. }\end{array}$ \\
\hline
\end{tabular}

\section{Conclusion:}

This review concluded that Self ligating brackets were not superior when compared to Conventionally ligating brackets during the initial alignment and levelling stage. Pain experience was independent of bracket type, but on insertion and removal of arch wire more pain was experienced with passive Self ligating brackets.

\section{References:}

[1]. Stolzenberg J 1935: The Russell attachment and its improved advantages. Int J Orthod Dent Child 21:837-840

[2]. Harradine N W T 2008. The history and development of self ligating brackets. Seminars in orthodontics 14: 5-18.

[3]. Kapur R Sinha P K, Nanda R S 1998. Frictional resistance of the Damon SL bracket. Journal of Clinical Orthodontics 32:485-489.

[4]. Lotfus B P,Artun J Nicholls T A, Stoner J A. 1999 Evaluation of friction during tooth movement in various bracket-arch wire combinations. American Journal of Orthodontics and Dentofacila Orthopedics 116: 336-345.

[5]. Miles P G, Weyant R J, Rustveld L 2006 A clinical trial of Damon 2 vs conventional twin brackets during initial alignment. Angle Orthodontist 76: 480-485.

[6]. Rohaya Meghat Abdul Wahab, Hartini Idris, Habibah Yacob, Sharul Hisham Zainal Ariffin 2012. Comparison of Self and Conventional ligating brackets in the alignment stage. European Journal of Orthodontics 34: 176-181.

[7]. Fleming PS, DiBiase AT, Sarri G, Lee RT 2009. Efficiency of mandibular arch alignment with 2 preadjusted edgewise appliances. Am J Orthod Dentofacial Orthop. ;135: 597-602.

[8]. Scott P, Sherriff M, DiBiase AT, Cobourne MT 2008. Perception of discomfort during initial orthodontic tooth alignment using a self-ligating or conventional bracket system: a randomized clinical trial. Eur J Orthod. 30:227-232.

[9]. Miles PG 2005. SmartClip versus conventional twin brackets for initial alignment: is there a difference? Aust Orthod J. $21: 123-127$.

[10]. Jones M, Chan C,b1992. The pain and discomfort experienced during orthodontic treatment: a randomized controlled clinical trial of two initial aligning arch wires. Am J Orthod Dentofacial Orthop. 102:373-381.

[11]. Pandis N, Polychronopoulou A, Eliades T, 2007. Self-ligating vs conventional brackets in the treatment of mandibular crowding: a prospective clinical trial of treatment duration and dental effects. Am J Orthod Dentofacial Orthop. 132:208-215.

[12]. Fleming PS, DiBiase AT, Sarri G, Lee RT, 2009. Mandibular arch dimensional changes with 2 preadjusted edgewise appliances. Am J Orthod Dentofacial Orthop. 136:340-347.

[13]. 13.Pandis N, Polychronopoulou A, Makou M, Eliades T. Mandibular dental arch changes associated with treatment of crowding using self-ligating and conventional brackets. Eur J Orthod. In press. 